\title{
AN INVESTIGATION OF CELL PHONE USES IN THE EDUCATIONAL ACTIVITIES AT THE UNIVERSITY LEVEL
}

\author{
Maksal Minaz \\ Lecturer in Department of Education, \\ Abdul Wali Khan University Mardan \\ maksalminaz@awkum.edu.pk \\ Ghazala Naheed Baig \\ Lecturer in Department of Education, \\ Abdul Wali Khan University Mardan \\ ghazala@awkum.edu.pk \\ Azmat Ali Shah \\ Lecturer in Department of Education, \\ Abdul Wali Khan University Mardan \\ azmatalishah@awkum.edu.pk
}

\begin{abstract}
The study investigated the uses of a cell phone in educational activities of students at a higher level. The recommendation of National Professional Standards on the use of ICT in education provides a strong theoretical background for the study. The objectives of the study focused on the investigation of the perception of teachers and students regarding the uses of the cell phone in educational activities and effective communication between students and teachers for educational progress. Adopting a descriptive research design, a survey was carried out to investigate one hundred respondents by using a self-developed questionnaire. The collected data was analyzed through percentage and findings were tabulated consequently which show that majority of respondent uses a cell phone for instructive activities and having positive effects on students' educational performances. Furthermore, the uses of a cell phone in educational activities facilitate teachers and students at the same level in organizing their teaching and learning activities.
\end{abstract}

Keywords: Cell phone, Students' National Professional Standards, Instructional Activities, etc.

\section{INTRODUCTION}

As the study was conducted by Javed \& Memon, (2016) they concluded that cell phones are undeniably convenient, helpful tools for the educational industry and can be a hurtful source of distraction depending on the attitude and use pattern of a student.

According to Mishra, (2010) the involvement of mobile phones in educational activities is the gateway to engage the students with modern and new technology and to prepare them in a sophisticated, easy, and accessible manner for modern education. As Bowen, Kyle \& Matthew, (2012) stated Purdue University a program that was started in 2009 to aware and raised the level of the students in M-Technology. This program facilitated the students to boost up their learning with advanced facilities provided by the environment and by the institutions. Many applications were installed in the cell phones for better interactions and social mobility of learners to communicate for their purpose of learning.

According to (Mishra, 2010) technology is providing ease of access in multiple fields like education, medical, engineering, and business, etc. A cell phone is one of the technologies which have helped to connect all human beings with each other. It is an electronic device with wireless communication for interconnection among human beings. Today cellphone is affordable and with the advanced technology of Weber services and data transmission/reception through the internet.

Dykes \& Knight, (2012) analyzed the uses of cell phone and was of the view that it is utilized for social interaction by teachers and students out of school premises. The uses of cell phones in school-based programs are instinctively similar to laptops and have a great contribution to the 
promotion of students learning. The ability of mobile phones to connect to the internet services for the purpose to increase the opportunities towards study materials in minimum time. School and classrooms are not the restricted areas because cell phones increased the access and opportunities of multiple channels of learning which are necessary for students' comprehensive development. The different features of a cell phone can further enhance students' adjective capacity and enable them to utilize it in their learning accordingly.

The uses of optical fiber technology towards access to the digital world have a space to enhance teaching and learning with diversity and more attraction (Javed \& Memon, 2016).

Multiple investigators and educationists have studied cell phones and their uses in instructive activities and found them more eye-catching and effective means for learning (Baran, 2014; Dawn, 2014; Dykes \& Knight, 2012; Javed \& Memon, (2016). Teacher's professional development was also studied by (Baran, 2014) where he concentrate on teacher education and the use of mobile technology in the professional development of teacher's skills. The literature studied in the article explains different dimensions of mobile technology use in teacher education. That dimension includes; integration of mobile learning into teacher education, theoretical and conceptual adoption of mobile, and some related to planning aspects of teacher education. The study also reported that its use was found beneficial for teachers (Baran, 2014).

Teachers and students have different types of visions regarding the uses of mobile technology during the teaching and learning process. Recent research on teacher perceptions regarding the uses of mobile technology illustrated that mobile technology was an effective and useful instructional aid to contribute during the learning process. It is the most ubiquitous invention which provides the fastest information and knowledge at the fingertips. The study revealed that schools among all of the institutions are the slowest organization in adopting it and that is why it is not more effective in educational activities (Dawn, 2014).

The Students are showing the most positive affinity towards the uses of the cell phone in a classroom and learning societies to educate. They considered it more effective for student-teacher interaction, construct feedback, and even for problem-solving and quick response. Students can get in touch with their teacher for assistance in their homework and school assignments. The uses of cell phones in school need a properly organized and well-explained policy which will further contribute to the enhancement of communication and interaction at the school level (Humble \& Thaden, 2010; Baran, 2014; Ahmad, 2020).

\section{OBJECTIVES OF THE STUDY}

The researchers have divided the problem into the following objectives;

1. To investigate the effective uses of the cell phone in the educational activities of students at the university level

2. To investigate the approaches of students regarding the uses of Cell phones at the university level.

3. To highlight the perceptions of teachers, about the use of cell phones for educational activities at the university level

4. To investigate that cell phone is an authentic/ precise way of communication between teachers and learners for academic development

\section{SIGNIFICANCE OF THE STUDY}

As theoretical foundations of the study linked with Lev Vygotsky's theory to Lovaszova, Michalickova \& Capay, (2015) multiple digital devices are used to support educational activities for indoor and outdoor learning situations such as cell phones, android phones, and personal digital assistants (PDAs). Therefore, the study is likely to identify the uses of the cell phone in educational activities at the university level. The study also signified its uses in the student's erudition as a learning tool. The study was significant as identified the development of M-learning modules for learning to students and particularly to those having low access to direct teaching and learning process. 


\section{STATEMENT OF THE PROBLEM}

The use of ICT is one of the $7^{\text {th }}$ standards in the National Professional Standards for Teacher Education (NPSTE) which needs to be realized in $21^{\text {st }}$-century education. It is the need of the $21^{\text {st }}$ century learner to assure their proficiency/competency in the use of all sorts of new educational technologies. Among those many technologies, the cell phone is a useful electronic device used for collecting, storing, analyzing, and disseminating information for learning. Therefore, a study was planned to investigate the uses of Cell Phones in educational activities among university students.

\section{REVIEW OF LITERATURE}

The use of cell phones for entertainment is not bad at all, but such games, social sites, and reliable/valid informative sites may be encouraged and identified for students which could not only satisfy their entertainment needs but also contribute positively towards their academic successes.

According to Dawn, (2014) in past, the communication was more expensive and inaccessible but now due to the advancement of technology, it brings new features and advanced models: facilities like internet/web browsers and other social applications have arrived for better interaction and communication with each other. (Ishii, 2006), Learners can easily connect with the web services, they use the social sites for the enhancement of learning capabilities and social communication. These sites are known as SNC (Social Network Cites). Gilroy, (2003) researched "the opinions of faculty regarding the use of cell phones in the classroom"; it generated different opinions about the use of cell phones in the classroom several have pointed out that it should be banned but the positive recommendation was that it should be utilized in an organized manner with some standards because students should have to reach beyond the barriers to archiving the new ideas through technology for quality education.

A project was designed by UNESCO for a contribution of Mobile learning for teachers in Europe by Dykes \& Knight, (2012) the project aimed to demonstrate that mobile learning-related projects boost up the interface and improve students and teachers interactions, it can be used to enhance the academic achievements. The goal was very specific related to teachers' professional and pedagogical expertise with students' learning capabilities. The project indicates that mobile learning improves/enhances teachers' capabilities in different areas in which the major ones included communication, self-assessment, and innovation. Through this project teachers used social sites to facilitate the students learning, the teachers used self-assessment approaches by recording their lectures and classrooms activities, to identify the areas in which expansion may be needed. The process has innovatively emerged with new ideas, creativity, and inspiration in the teaching and learning process through mobile technology.

Bowen, Kyle, Matthew \& Pistilli, (2012) conducted a study that how students use their cell phones in educational related activities, they suggest that educational institutions would make available mobile services to students easily and accessible for teachers to interact easily. The supported applications must be provided to students to support outdoor activities. Cell phones in the classroom are creating an atmosphere where cognitive, affective, and psychomotor abilities of the mentor and facilitator work at a time for the same purpose. The result shows that some of the facilitators should be aware of using cell phones in the classroom. They conclude that the mega applications to enhance like Blogging \& Twitter, Facebook, Wiki \& Smartboard, Photographs, Video, Podcasting, Voice recording, calculators, polling, research, calendars, scavenger hunts and taking notes (Kolb, 2011).Cell phones permitted with formal and informal sustain the learners to intermingle with their classroom environment and society (Diaz, 2012).

According to Mohammadi, Sarvestani \& Nouroozi, (2020) the idea that technology can revolutionize education is not new. However, the Internet coupled with mobile is more affordable end-user gadgetry now lends itself as an enormously powerful digital medium to enhance the teaching and learning experiences across the globe. Developments in information technology have enabled the "personalization" of the learning experience by providing access to learning and assessment resources anywhere, anytime. The aim of e-Learning in Punjab was to facilitate and encourage M-learning in the classrooms and outside classroom activities.

Besides all of the benefits of using modern technologies in educational activities, some of the researchers have the opinion that some instructors have banned electronic devices (projector, computer, multimedia, cell phone) in their classrooms with positive results (Bugeja, 2007). Bugeja, 
(2007) argued that soon all faculty members will include policies regarding the in-class uses of electronic devices during learning activities. However, Gilroy, (2003) argued that the opinions of faculty regarding the utilization of cell phones in the real classrooms they wishing to ban them, and others felt that even policies regarding the utilization of cell phones must be drawn. To understand these issues, it is important to carefully investigate these differences in the opinions of researchers. Therefore Dawn, (2014) provides a rationale for the inherent differences in perspective between students and faculty. It was reported that faculty can't easily use M-technology due to insufficient knowledge.

Keeping in view the above literature, this study concentrates on the uses of cell phones in the educational activities of university students for quality education. As the above studies cited are done in the developed countries, therefore, the researchers got interested to investigate it in the local context, apart from that the integration of ICT into education main emphasis in educational institutions. National Professional Standards for Teacher Education in Pakistan also focused on the use of modern technology in the process of teaching and learning.

\section{THEORETICAL FRAMEWORK}

One of the major function of theoretical framework is to direct a course of action. The concept provides a direction to provide some logic for the research. The section also provides an understanding of how the theory illuminates study on uses of a mobile phone and educational activities of students. The study was inspired by the social learning theory by Lev Vygotsky, (1962) social learning theories explain that people learn from culture, environment and the social context and update the teachers to construct energetic learning communities. It is the nature of human beings that they learn through interactions, communication, and collaboration with other human beings. Vygotsky, (1962) examined how our social environment influence the learning process. He suggested that learning takes place through interactions with peers, teachers, and other experts. As concluded by Minaz, Tabassum \& Idris, (2017) consequently, teacher's foremost responsibility to create a learning environment that boost up the ability among students to communicate, interact and collaborate with positive and appropriate feedback. Moreover, Vygotsky, (1962) argues that culture is the primary determining factor for knowledge construction.

He explains the supreme rule of interaction through people behave sophisticatedly, and reshaped all of the individual abilities. As stated by Roberts, (2004) that mobile support computersupported collaborative culture indoor class and outdoor class uses of handheld mobile devices similar to cell phones, smartphones, and personal digital assistants (PDAs) to generate collaborative learning environment. Therefore, Veerabhadram \& Lombard, (2015); Naismith, Sharples, \& Ting, (2005) collaborative learning theory involves peer-to-peer learning that fosters deeper thinking in the classroom. As (Naismith, Sharples \& Ting, 2005; Kimball, 2001) argued that social learning theory proposes that group learning helps students to develop their higher-level of thinking, oral communication, self-management, and leadership skills. Students also have opportunity to build upon their leadership and organizational skills.

M-Learning is purposeful technology; (Diaz, 2012). As Naismith, Sharples \& Ting, (2005) recommended examples for mobiles learning:

a. Behaviorist: M-Learning changes the learner's actions towards learning approaches. Behavior change is because of a stimulus with a response.

b. Collaborative: M-learning activities boosting social grouping. Availability of different applications in cell phones is the cause of prosperous social interactions and collaboratively shares the knowledge within a social group.

c. Informal and lifelong: M-learning provides informal and lifelong opportunities to enhance the knowledge of an individual.

d. Learning and teaching support: cell phone is supportive in learning and teaching situations to assess the student's capabilities in the classroom and outside. For example, access to the learning management system, schedules, library resources, or student support services.

e. Constructivist: Learners performs as an active participant in such activities due to cell phone in the classroom and construct new dreams for their conceptual knowledge.

f. Situated: learning through m-learning facilitates students to relate the context with realworld experiences. 


\section{MATERIALS AND METHODS}

The study was descriptive in nature and a survey was carried out to collect data from the respondents. A questionnaire was used for data collection which was pilot tested and its validity was ensured through critical analysis and keen observation in the light of the literature review. There were twentysix items (26) in the questionnaire which concentrated on the uses of cell phones in educational activities at the university level.

The population of the study was all students of Abdul Wali Khan University Mardan enrolled in social sciences departments were constituted. The number of four departments Education, Sociology, Political Science and Management Sciences were selected. The students enrolled in the BS program were selected for the survey. Therefore, total numbers of one hundred students of which twenty-five from each department were selected through convenience sampling technique (Nonprobability). Researcher used convenience sampling technique in situations where additional inputs are not necessary for the principal research. There are no criteria required to be a part of this sample. Thus, it becomes incredibly simplified to include elements in this sample. The researcher chooses members merely based on proximity and doesn't consider whether they represent the entire population or not. Using this technique, we observe habits, opinions, and viewpoints in the easiest possible manner Gay, Miles \& Airasian, (2011) were investigated through a self-developed questionnaire. The collected data was analyzed through percentage.

Table No 1. Students Literacy of using Cell phones for Academic Purpose

\begin{tabular}{|c|c|c|c|c|}
\hline \multirow{3}{*}{$\begin{array}{l}\text { Statement } \\
\text { You are well aware of all the } \\
\text { applications/options of your } \\
\text { Cell phone? }\end{array}$} & Description & Respondents & Percentage & Total \\
\hline & Yes & 80 & $80 \%$ & \multirow[b]{2}{*}{100} \\
\hline & No & 20 & $20 \%$ & \\
\hline Can you use your mobile for & Yes & 78 & $78 \%$ & \multirow{3}{*}{100} \\
\hline academic purposes? & No & 22 & $22 \%$ & \\
\hline Do you understand the & Yes & 90 & $90 \%$ & \\
\hline $\begin{array}{l}\text { abbreviated language of Cell } \\
\text { phone text? }\end{array}$ & No & 10 & $10 \%$ & 100 \\
\hline $\begin{array}{l}\text { Are you using Audio Video } \\
\text { software for academic } \\
\text { discussion? }\end{array}$ & $\begin{array}{l}\text { Yes } \\
\text { No }\end{array}$ & $\begin{array}{l}75 \\
25\end{array}$ & $\begin{array}{l}75 \% \\
25 \%\end{array}$ & 100 \\
\hline
\end{tabular}

The above table shows that the tendency of the student's literacy regarding using cell phones is satisfactory; the analysis shows that the percentage of students who were aware of all of the options/applications of using a cell phone is more satisfactory than those who have less knowledge of mobile application and opportunities. The students' percentage is $78 \%$ who easily used applications of calculation and scheduling on the cell phone for academic purposes and those who were less aware was $22 \%$. Hence, $90 \%$ students understand the language of short text messages or abbreviated language and only ten percent $10 \%$ students were not understand. The students were responded that they also engage on multiple social networks to enhance academic performance, the percentage was $75 \%$ showed the tendency of the students towards M-learning.

Table No. 2. Use of Cell Phones for Communication among Students and Teachers

\begin{tabular}{lllll}
\hline Statement & Description & Respondents & Percentage & Total \\
\hline $\begin{array}{l}\text { Your teacher uses the cell phone } \\
\text { during class for instructional }\end{array}$ & No & 37 & $37 \%$ & \\
matters. & & 63 & $63 \%$ & 100 \\
$\begin{array}{l}\text { I easily contact my teachers for } \\
\text { study }\end{array}$ & Nes & 69 & $69 \%$ & \\
$\begin{array}{l}\text { I use my cell phone for contacting } \\
\text { my family members. }\end{array}$ & Yes & 31 & $31 \%$ & 100 \\
I contact my friends through & Yes & 20 & $80 \%$ & \\
mobile phone for study & No & 60 & $20 \%$ & 100 \\
\hline
\end{tabular}


The table shows that cell phone was frequently used among students and teachers for academic discussions. The percentage of teachers by means of cell phones in the instructional activities is only 37 (37\%), which means teachers use pedagogical techniques in the classroom. The percentage of students who contact teachers for educational activities were $69 \%$ and $31 \%$ of students do not agreed with the statement. Eighty $(80 \%)$ students contact with family members and sixty $(60 \%)$ students were communicated with groups to discuss complications associated to educational activities.

Table No. 3. Using of Cell phones for Social Media and General Information

\begin{tabular}{|c|c|c|c|c|}
\hline Statement & Description & Respondents & Percentage & Total \\
\hline I always use Facebook/ twitter/ & Yes & 78 & $78 \%$ & \\
\hline $\begin{array}{l}\text { Skype/ Viber/ Games on cell } \\
\text { phone. }\end{array}$ & No & 22 & $22 \%$ & 100 \\
\hline I always take academic advantage & Yes & 74 & $74 \%$ & \\
\hline by the use Twitter/Skype/e-mail & No & 26 & $26 \%$ & 100 \\
\hline I always visit social sites on my & Yes & $60 \%$ & $60 \% \%$ & \\
\hline cell phone. & No & $40 \%$ & $40 \%$ & 100 \\
\hline
\end{tabular}

The above table shows that the $78 \%$ percentage of students were frequently used various social sites like Facebook/Twitter/Skype/Viber/Games on cell phone and $22 \%$ were not aware of social networking. Larger number of students $74 \%$ were took advantage from social networking and used social applications like Twitter, Skype and email. Hence, 26 percent of students remained unaware of social applications. Number of sixty (60\%) students responded that they frequently visit social networking for educational activities while $40 \%$ responded "No" the statement.

Table No. 4. Use of Cell Phones for Entertainment/Leisure Activities

\begin{tabular}{lllll}
\hline Statement & Description & Respondents & Percentage & Total \\
\hline I enjoy music on my cell phone. & Yes & 72 & $72 \%$ & \\
& No & 28 & $28 \%$ & 100 \\
I tease the class fellow by sending & Yes & 22 & $22 \%$ & \\
missed calls. & No & 78 & $78 \%$ & 100 \\
I always play mind games on my & Yes & 85 & $85 \%$ & \\
cell phone. & No & 15 & $15 \%$ & 100 \\
\hline
\end{tabular}

The above table shows that students enjoy spending leisure time on cell phones. The percentage of the students who were enjoyed music on cell phones is greater than those who did not like attend music on cell phones. Number of seventy two (72\%) of students like to enjoyed music on cell phone and $28 \%$ of students were not adored music on cell phones. The $22 \%$ percentage of the students were used cell phone to tease their friends although (78\%) were disagree with the statement, in spite of all these results eighty five (85\%) responded were always played mind games on cell phone and only fifteen (15\%) students were responded "No" the statement.

Table No. 5. Students' perception regarding the use of cell phones is a wastage of time

\begin{tabular}{lllll}
\hline Statement & Description & Respondents & Percentage & Total \\
\hline $\begin{array}{l}\text { Using of cell phone during class } \\
\text { is ges }\end{array}$ Yood for academic & No & 15 & $15 \%$ & \\
$\begin{array}{l}\text { development. } \\
\text { The cell phone is helpful for the }\end{array}$ & Yes & 85 & $85 \%$ & 100 \\
$\begin{array}{l}\text { preparation of the examination. } \\
\text { The use of mobile reduced my }\end{array}$ & Yes & 30 & $30 \%$ & \\
study habit. & No & 70 & $70 \%$ & 100 \\
$\begin{array}{l}\text { The use of cell phones produces } \\
\text { disturbance in the class. }\end{array}$ & Yes & 69 & $69 \%$ & \\
\hline
\end{tabular}

The above table shows that only (15\%) students were agree with the statement that cell phone during in-class activities was worthy for academic development while $(85 \%)$ were not agree. 
Statement regarding cell phone is helpful in the preparation of examination shows that thirty $(30 \%)$ students were agreed while $(70 \%)$ students were not agree. The percentage of students regarding the statement that mobile reduced the habit of study is sixty-nine $(69 \%)$ on the other hand $(31 \%)$ were responded "No". Number of eighty eight (88\%) students responded that cell phone was one of the cause of disturbance in classroom during educational activities while only (12\%) were responded that mobile were not the reason.

\section{SUMMARY}

The study was an investigation about the effective uses of the cell phone in educational activities at the university level. A self-developed questionnaire was used by the researcher and administered to collect the data from sampled students. Data were analyzed by using percentages. The major findings of the study; that majority of the students used a cell phone for academic development and interact with teachers and family for problem-solving, and difficulties related to academic development at the university level. It was also revealed that students used cell phones for their leisure time like refreshment/enjoyment. The cell phone was a useful electronic device used for student and teacher interaction, and an easy way of communication and instant feedback regarding educational activities.

\section{FINDINGS}

The data concealed that majority of students were literate regarding using a cell phone for academic development. Data revealed that students distinguish major options of cell phones; they can use multiple applications like a calculator for problem-solving to set their life routine, scheduled events on the cell phone for academic purposes and those who do not was $22 \%$. The student's also corresponded stay connected with social networks for academic development.

The study revealed that majority of university students and teachers were frequently used cell phones in various activities like academic discussions, debates, formal and informal communication. The majority of teachers used pedagogical techniques in the classroom and majority of students were easily contact teachers for academic purposes. Students responded that they used cell phone to communicate parentages for the solution of academic problems. The greater chunk of students communicated with friends to discuss difficulties associated to education Ahmad, (2020).

The study was found that the majority of students were spent a large amount of time on cell phones therefore the majority of students were responded that they enjoyed music on cell phones, played games, send and share light jokes etc.

Majority of students used social networking like Facebook/Twitter/Skype/Viber/Games on cell phone and a very short number of students have no interest as result majority of students were used numerous applications on cell phones. Students responded that they improved academic and social circle from social sites.

Despite the fact that students were took deeply interest in using cell phones in educational activities nevertheless some of the students were not in the favor of using the cell phone frequently during the classroom, the data also was revealed that students did not agree of using cell phones during the summative assessment, therefore they also agreed that regular use of cell phone causes depletion of study hours.

\section{CONCLUSIONS}

It was concluded from the data that the majority of university students were used mobile phones for collaborative learning activities. The student used a cell phone during class and participated in activities dynamically. The study revealed that mobile phone was the best way to communicate with others, and also the superlative technique for searching relevant study material. Students also used the internet facility on their mobile phones during class out of the class and in library. The mobile phone was the best equipment for the students because students learnt huge knowledge which facilitated in their educational activities. But with all these advantages mobile phone has their side effects which disrupt the teaching-learning process in the classroom and waste precious time of the students as well as the teachers. It may become the cause of the wastage of intellectuals and financial resources. Since majority of students instead of concentrating on their study may keep themselves busy in sending text messages that also irritate teachers. The use of this technology may be banned in educational institutions and only small number of students took benefit from internet. 


\section{RECOMMENDATIONS}

Cell phones manufacturing companies might produce low caste cell phones with highly sophisticated software and the latest technologies to make the cell phone ready to be a full substitute of Interactive Radio Instruction and could be used as an option of distance learning device. Educational videos portals available in cell phone play stores such as TED might be providing access without the internet if possible.

Several University students used cell phones in their daily life regularly therefore, activities such as enhancing vocabulary, speaking and listening skills search online dictionaries, e-mail skills and etymological skills should be focused on by the teachers during M-Learning.

A guide using cell phones in educational activities, particularly for exam preparation through conferences and chat rooms is recommended. The teacher should use collaborative ways of teaching to engage students during in-door class activities and outdoor activities. All the cooperative teaching activities including, think, peer \& share, jigsaw, and group leader/discussion can also be utilized in this regard. Awareness about the code of conduct in the use of cell phones in educational institutions must be ensured through strong campaigns and advertisements.

\section{REFERENCES}

Ahmad, T. (2020). Student Perceptions on Using Cell Phones as Learning Tools: Implications for Mobile Technology Usage in Caribbean Higher Education Institutions. PSU Research Review, Vol. 4 No. 1, pp. 25-43. https://doi.org/10.1108/PRR-03-2018-0007.retrived from https://www.frontiersin.org/articles/10.3389/feduc.2020.00016/full

Bowen, Kyle., Matthew D., \& Pistilli. (2012). Student Preferences for Mobile App Usage. (Research Bulletin) Louisville, CO: EDUCAUSE Center for Analysis and Research, September 25, 2012, Retrieved from http://www.educause.edu/ecar S

Baran, E. (2014). A Review of Research on Mobile Learning in Teacher Education. Educational Technology \& Society, 17 (4), 17-32.

Bugeja, M. (2007). Distractions in the Wireless Classroom. Chronicle of Higher Education, 53(21), $\mathrm{C} 1-\mathrm{C} 4$.

CLA. (2006). Classification of learning activities -Manual European Commission, Eurostat Unit F4, Battement Jean Monnet, Office BECH-B3/427, L-2920 Luxembourg ISSN 1725-0056

Dawn, G. K. (2014). The perception of teachers toward the use of mobile technology as a tool to engage students in learning. Indiana State University. Pro-Quest Dissertations \& Theses Gridworks.

Diaz, V. (2012). Framing Mobile Initiatives to Measure Impact. Proceedings of M-Learn 2008, available from http://www.mlearn.org/ mlearn2008.

Dykes, G., \& Knight, H. R. (2012). Mobile Learning For Teachers in Europe; Exploring the Potential of Mobile Technologies to Support Teachers and Improve Practice. France: United Nations Educational, Scientific and Cultural Organization.

Gay, L.R, Miles, G. E., \& Airasian, P. (2011) Educational Research: Competencies for Analysis and Applications. 10th Edition, Pearson Education International, Boston.

Gilroy, M. (2003). Invasion of the classroom cell phones. The Education Digest, 69(6), 56-60.

Humble \& Thaden, M. B. (2010). Student Reflective Perceptions of High School Educational Cell Phone Technology Usage. The Journal of Technology Studies, 10-15.

Ishii, K. (2006). Implications of mobility: The uses of personal communication media in everyday life. Journal of Communication, 56, 346_365. doi:10.1111/j.1460 2466.2006.00023.x

Javed, R., Memon, S., \& Memon, F. U. (2016). The impact of cell phone usage in the education Industry. Singaporean Journal of Business Economics, And Management Studies Vol.4, No.10, 2016. https://www.researchgate.net/publication/334731836

Kimball, L. (2001). Managing distance learning: New challenges for faculty. In R. Hazemi, S. Hailes, \& S. Wilbur (Eds.), The Digital University: Reinventing the Academy (pp. 25-38). Berlin, Germany: Springer Verlag.

Mishra, A. R. (2010). Cellular Technologies For Emerging Markets 2g, 3g, And Beyond. West Sussex, United Kingdom: John Wiley \& Sons, Ltd. 
Minaz, M., Tabassum, R., \& Idris, M. (2017). An Experimental Study of the Performance of Prospective Teachers of Flipped Classroom and Non-Flipped Classroom. Pakistan Journal of Education Vol. 34, No. 2, 2017, 167-182

Mohammadi, M., Sarvestani, S. M., \& Nouroozi, S. (2020). Mobile Phone Use in Education and Learning by Faculty Members of Technical-Engineering Groups: Concurrent Mixed Methods Design. Digital Education https://doi.org/10.3389/feduc.2020.00016.

Naismith, L., Sharples, M., \& Ting, J. (2005). Evaluation of CAERUS: A Context-Aware Mobile Guide. University of Birmingham, UK.

Neff, S. N. (n.d). Lev Vygotsky and Social Learning Theories. Retrieved from https://jan.ucc.nau.edu/lsn/educator/edtech/learningtheorieswebsite/vygotsky.htm.

Roberts, S. T. (2004). Online Collaborative Learning: Theory and Practice. Published in the United States of America by Information Science Publishing (an imprint of Idea Group Inc.) $701 \mathrm{E}$. Chocolate Avenue, Suite 200 Hershey PA 17033 Tel: 717-533-8845 Fax: 717-533-8661 Email: cust@idea-group.com Web site: http://www.idea-group.com

Veerabhadram, P., \& Lombard, A. (2015). A Theoretical Framework for Design Theories in Mobile Learning: A Higher Education Perspective. Dubai UAE Jun 18-19,17 (6) Part XIV.

Vygotsky, L. S. (1962). Thought and Language. Cambridge, MA: MIT Press. (Original work published in 1934).

Walter, Aadilah., \& Jansen, G. J. (2012). Smartphone Application usage Amongst Students at a South African University IST-Africa 2012 Conference Proceedings, (pp. 1-11).

Yousaf, I. M. (2007). Effectiveness of Mobile learning in distance education.Turkish Online Journal of Distance Education 8(4). DOAJ License CC BY-NC-SA 4.0. https://www.researchgate.net/publication/26477395 